\title{
Evaluation of FRET real-time PCR assay for rapid detection and differentiation of Plasmodium species in returning travellers and migrants
}

\author{
Innocent Safeukui*1,5, Pascal Millet ${ }^{1,2,3}$, Sébastien Boucher ${ }^{1}$, \\ Laurence Melinard ${ }^{1}$, Frédéric Fregeville ${ }^{2}$, Marie-Catherine Receveur ${ }^{4}$, \\ Thierry Pistone ${ }^{4}$, Pierre Fialon ${ }^{2}$, Philippe Vincendeau ${ }^{1,2}$, Hervé Fleury ${ }^{1}$ and \\ Denis Malvy ${ }^{3,4}$
}

\begin{abstract}
Address: ${ }^{1}$ Pôle de Biologie Moléculaire, CHU de Bordeaux, Hôpital Pellegrin, Place Amélie Raba Léon, 33076 Bordeaux Cedex, France, ${ }^{2}$ Laboratoire de Parasitologie, CHU de Bordeaux, 1 rue Jean Burguet, 33071 Bordeaux Cedex France, ${ }^{3}$ Centre René Labusquière, Université Victor Segalen Bordeaux 2,146 rue Léo Saignat, 33076 Bordeaux Cedex, France, ${ }^{4}$ Travel clinic and Imported Diseases Units, Department of Internal Medicine, University Hospital Centre, 1 rueJean-Burguet, 33071 Bordeaux Cedex, France and ${ }^{5}$ Safeukui Noubissi Innocent, Institut Pasteur, Unité d'Immunologie Moléculaire des Parasites, URA CNRS 2581, 28 Rue du Dr Roux, 75075 Paris, France
\end{abstract}

Email: Innocent Safeukui* - safeukui@pasteur.fr; Pascal Millet - pascal.millet@u-bordeaux2.fr; Sébastien Boucher - sebastien.boucher@viro.ubordeaux2.fr; Laurence Melinard - melinardlaurence@hotmail.com; Frédéric Fregeville - frederic.fregeville@chu-bordeaux.fr; MarieCatherine Receveur - marie-catherine.receveur@chu-bordeaux.fr; Thierry Pistone - thierry.pistone@chu-bordeaux.fr; Pierre Fialon - pierre.fialon@chu-bordeaux.fr; Philippe Vincendeau - philippe.vincendeau@parasito.u-bordeaux2.fr; Hervé Fleury - herve.fleury@viro.u-bordeaux2.fr; Denis Malvy - denis.malvy@chu-bordeaux.fr

* Corresponding author

Published: 28 April 2008

Malaria Journal 2008, 7:70 doi:10.1186/1475-2875-7-70

This article is available from: http://www.malariajournal.com/content/7///70

(c) 2008 Safeukui et al; licensee BioMed Central Ltd.

This is an Open Access article distributed under the terms of the Creative Commons Attribution License (http://creativecommons.org/licenses/by/2.0), which permits unrestricted use, distribution, and reproduction in any medium, provided the original work is properly cited.
Received: 26 September 2007
Accepted: 28 April 2008

\begin{abstract}
Background: A simple real-time PCR assay using one set of primer and probe for rapid, sensitive and quantitative detection of Plasmodium species, with simultaneous differentiation of Plasmodium falciparum from the three other Plasmodium species (Plasmodium vivax, Plasmodium ovale and Plasmodium malariae) in febrile returning travellers and migrants was developed and evaluated.
\end{abstract}

Methods: Consensus primers were used to amplify a species-specific region of the multicopy I8S rRNA gene, and fluorescence resonance energy transfer hybridization probes were used for detection in a LightCycler platform (Roche). The anchor probe sequence was designed to be perfect matches to the I8S rRNA gene of the fourth Plasmodium species, while the acceptor probe sequence was designed for $P$. falciparum over a region containing one mismatched, which allowed differentiation of the three other Plasmodium species. The performance characteristics of the realtime PCR assay were compared with those of conventional PCR and microscopy-based diagnosis from 119 individuals with a suspected clinical diagnostic of imported malaria.

Results: Blood samples with parasite densities less than $0.01 \%$ were all detected, and analytical sensitivity was 0.5 parasite per PCR reaction. The melt curve means Tms (standard deviation) in clinical isolates were $60.5^{\circ} \mathrm{C}\left(0.6^{\circ} \mathrm{C}\right)$ for $P$. falciparum infection and $64.6^{\circ} \mathrm{C}\left(1.8^{\circ} \mathrm{C}\right)$ for non- $P$. falciparum species. These Tms values of the $P$. falciparum or non- $P$. falciparum species did not vary with the geographic origin of the parasite. The real-time PCR results correlated with conventional PCR using both genus-specific (Kappa coefficient: 0.95 , 95\% confidence interval: $0.9-1$ ) or $P$. 
falciparum-specific $(0.91,0.8-1)$ primers, or with the microscopy results $(0.70,0.6-0.8)$. The realtime assay was $100 \%$ sensitive and specific for differentiation of $P$. falciparum to non- $P$. falciparum species, compared with conventional PCR or microscopy. The real-time PCR assay can also detect individuals with mixed infections ( $P$. falciparum and non-P. falciparum sp.) in the same sample.

Conclusion: This real-time PCR assay with melting curve analysis is rapid, and specific for the detection and differentiation of $P$. falciparum to other Plasmodium species. The suitability for routine use of this assay in clinical diagnostic laboratories is discussed.

\section{Background}

Plasmodium falciparum and Plasmodium vivax account for the majority of malaria cases worldwide [1]. Plasmodium falciparum is responsible for complications and death, mainly in non-immune individuals. On the other hand, $P$. vivax and Plasmodium ovale induce mild malaria symptoms restricted to fever with rare complications, while Plasmodium malariae infections result in mild symptomatic malaria. Furthermore, $P$. vivax and $P$. ovale produce dormant liver stages that may result in relapse of infection months to years later, while $P$. malariae infections can persist for decades, although dormant liver forms are not thought to occur.

It is currently estimated that 50-80 million individuals from industrialized countries visit malaria-endemic areas each year and approximately 10,000-30,000 travellers contract malaria [2], among which severe malaria accounts for approximately 5\% (range 1-38\%) [3], with a mortality rate ranging from $0.6 \%$ to $3.8 \%$ mainly resulting mostly from late and/or misdiagnosis, and delayed treatment administration [4-8]. Because about $90 \%$ of travellers who contract malaria will not become ill until returning home, preventing malaria-associated morbidity and mortality requires improved rapid and accurate laboratory diagnostic tools detecting low parasitaemia and differentiating febrile patients with $P$. falciparum from the other Plasmodium species. Such diagnostic, performed at the time of patient admission, will allow a prompt and adequate treatment and follow-up [9].

Light microscopy of thick and thin Giemsa-stained blood smears remains the gold standard for malaria diagnostic [10]. However, even in expert hands (increasingly missed in industrialized countries), microscopy demonstrated limitations, mostly related to low sensitivity (detection limit: $10-50$ trophozoites $/ \mu \mathrm{l})$ and misdiagnosis $[4,11-$ 15]. In some case, parasite morphology is damaged due to exposition to prophylactic medication or auto-medication, making malaria biological diagnosis more difficult.

Alternative methods for laboratory diagnostic of malaria have been developed, including fluorescence microscopy of parasite nuclei stained with acridin orange and rapid dipstick immunoassays. The advantages offered by these methods, such as the fact that a result can be obtained within half an hour by non-skilled technicians, are tempered by three limitations reviewed by Moody et al [16]: 1) the dipstick tests do not improve sensitivity over microscopy and the sensitivity decreases as parasitaemia falls below 100 parasites/ $\mu \mathrm{l}$ [17]; 2) false positives are observed, particularly after treatment, as the parasite antigens detected can remain in the circulation following parasite clearance, or in the presence of pneumococcal meningitis infection [18]; and 3) many dipstick tests are specific to $P$. falciparum infections.

A variety of PCR-based techniques have been developed for the genus or species-specific diagnosis of malaria parasite infection $[11,13,19-21]$. While demonstrating increased sensitivity and specificity, they remained labour-intensive, time-consuming and prone to carry more DNA contamination during manipulation of postamplification products. The recent advance of a real-time quantitative PCR technique has proven usefulness in various applications, including parasite detection, species differentiation, gene expression and regulation, and allelic discrimination [22-30]. However, the large majority of developed real-time PCR assays used many set of primers and/or probes to analyse each sample, thus increasing cost and reliability.

To date, one fluorescence resonance energy transfer (FRET) real-time PCR assay using one set of primer and probe [31], and two others real-time PCR methods using one set of primer and SYBR green dye [26,32] for Plasmodium sp. identification and species differentiation have been evaluated. The principal limitation of these assays was the lack of sensitivity of parasite detection: two to 30 parasites/ $\mu$ l of blood according to the study. Furthermore, the real-time PCR approach using SYBR green dye did not avoid the quantification of non-specific amplification products [33]. Here, a real-time PCR assay using a single set of primer and FRET hybridization probe for sensitive and quantitative detection of Plasmodium species, with simultaneous differentiation of $P$. falciparum from other human Plasmodium species was developed and evaluated. Results from the real-time PCR assay were compared to conventional PCR methods and microscopy examination of blood smears. 


\section{Methods \\ Origin of the clinical specimens and DNA template preparation}

A total of 119 blood samples were collected in EDTA tube from travellers or migrants admitted to the Saint André University Hospital in Bordeaux, with suspected clinical malaria from years 2000 to 2006. Blood samples were collected before the initiation of the antimalarial treatment. One aliquot of each sample was used for routine biological diagnostic in the Biology Laboratory and the other one was stored at $-80^{\circ} \mathrm{C}$ until use. DNA was extracted from $200 \mu \mathrm{l}$ of blood using either the QIAamp DNA mini Kit (QIAGEN) or using an automated DNA extraction machine (MAGNA PURE LC, Roche Diagnostics, Indianapolis, Ind.) according to the manufacturer's instructions. The samples were run blindly for real-time PCR and conventional PCR assays.

\section{Primer and probe design}

The primers and probes were designed using the multicopy, stable and highly conserved [34] 18S rRNA gene single-stranded sequences of Plasmodium species available from GenBank ( $P$. falciparum, accession number: AL010278; P. vivax, accession number: U83877; P. ovale, accession number: $\underline{\mathrm{L} 48986}$ and $P$. malariae, accession number: $\underline{\mathrm{M} 54897}$ ). The primers and probes are summarized in Table 1. Figure 1 shows their position and the alignment results of the $18 \mathrm{~S}$ rRNA gene single-stranded sequences using the ClustalW multiple sequence alignment program (EMBL - European Bioinformatics Institute, Cambridge, UK). The sequences of the primers and the anchor FRET hybridization probe were designed to be perfect matches (i.e., $100 \%$ homologous) to the P. falciparum, $P$. vivax, $P$. ovale and $P$. malariae sequences. The sequence of the acceptor FRET hybridization probe was designed on the basis of one nucleotide mismatch difference that distinguish the $18 \mathrm{~S}$ rRNA gene of the $P$. falciparum from those of the three other Plasmodium species. To ensure proper hybridization of the probe to the target sequence, oligonucleotides with a Tm at least $5^{\circ} \mathrm{C}$ higher than the actual annealing/extension temperature were chosen as probes. The 3 ' end of the anchor FRET hybridi- zation probe was labelled with fluorescein isothiocyanate (FITC) and the 5 ' end of the acceptor FRET hybridization probe with LCRed705. Possible oligonucleotide dimers formation and/or self-complementarity and the theoretical melting temperatures of primers and probes (Tms) were calculated using Oligo programme version 4 (LightCycler Probe Design Software, Roche). Oligonucleotide primers and probes were obtained from Eurogentec and Proligo, respectively. The $P$. falciparum-specific primers were designed to amplify a 120-bp region from the cytochrome $c$ oxidase subunit 1 ( $\operatorname{cox} 1$ ) mitochondrial gene.

\section{FRET real-time PCR}

Amplification and detection

Purified DNA templates were amplified in a LightCycler analytical PCR system (version 6.0, Roche Diagnostics, Indianapolis, Ind.). The real-time PCR was performed using the "LightCycler DNA Amplification Kit Hybridization Probes" (Roche Diagnostics, Mannheim, Germany), according to the manufacturer's instructions. The reaction was realized in a final volume of $20 \mu \mathrm{l}$ in each capillary tube containing $3.0 \mathrm{mM} \mathrm{MgCl}, 0.5 \mu \mathrm{M}$ of each primer, $0.25 \mu \mathrm{M}$ of acceptor probe, $0.20 \mu \mathrm{M}$ of anchor probe, $2 \mu \mathrm{l}$ of 10× LightCycler-FastStart DNA master hybridization probe mixture, and $10 \mu \mathrm{l}$ of extracted DNA. After a short centrifugation (700 $\mathrm{g}$ for $10 \mathrm{~s}$ ), the sealed capillaries were placed into the LightCycler. The PCR program ran as follows: (i) $8 \mathrm{~min}$ at $95^{\circ} \mathrm{C}$ for enzyme activation and DNA denaturation, and (ii) 45 PCR amplification cycles consisting of $95^{\circ} \mathrm{C}$ for $15 \mathrm{~s}, 57^{\circ} \mathrm{C}$ for $10 \mathrm{~s}$, and $72^{\circ} \mathrm{C}$ for $8 \mathrm{~s}$. The temperature transition rate was $20^{\circ} \mathrm{C} / \mathrm{s}$ in the denaturation and annealing steps and $5^{\circ} \mathrm{C} / \mathrm{s}$ in the polymerization step. In the final cycle, the melting curve was obtained by initially heating to $95^{\circ} \mathrm{C}$ for $1.50 \mathrm{mn}$ and subsequently cooling the samples to $45^{\circ} \mathrm{C}$ for $30 \mathrm{~s}$. A final heating step to $95^{\circ} \mathrm{C}$ was realized with a controlled temperature transition rate of $0.4^{\circ} \mathrm{C} / \mathrm{s}$. The resulting fluorescence was recorded starting at the final $95^{\circ} \mathrm{C}$ heating step using the parameter "continuous mode" and the F3/F1 channel.

Table I: Primers and probes selected for PCR of Plasmodium I8S rRNA and coxI genes

\begin{tabular}{|c|c|c|c|c|}
\hline & & & Sequence & Target gene \\
\hline \multirow[t]{4}{*}{ Primers } & Genus specific & Forward & 5'-GTTTAAGGCAACAACAGGT-3' & I8S rRNA \\
\hline & & Reverse & 5'-CAATAATCTATCCCCATCACGA-3' & \\
\hline & P. falciparum specific & Forward & 5-TTACATCAGGAATGTTATTGC-3 & $\operatorname{coxl}$ \\
\hline & & Reverse & 5-ATATTGGATCTCCTGCAAAT-3 & \\
\hline \multirow[t]{3}{*}{ Probes } & & Sensor & 5'-ACTCGTTATACATATCAGTGTAGCACGC (FLU)-3' & I8S rRNA \\
\hline & & & $5 '-(\operatorname{Red} 705)$ & \\
\hline & & Anchor & GCAGCCTAGTTCATCTAAGGACATCACAG (P)- 3' & \\
\hline
\end{tabular}

Amplicon length: P. ovale: 198 pb (I662 - 1859); P. vivax: 78 pb (I435 - 16 |2); P. malariae: 207 pb (I873 - 2079) and P. falciparum: I90 pb (I035 1225). The nucleotide positions are those reported in GenBank 

P. ovale
P. Vivax
P. malariae
P. falciparum

ÄGÄGGẢCGÄTGTGTGTCTẢACACẢAGGÄÄTTTAHGGCAHCÄCAGGTCTGTGATGTCC 1692

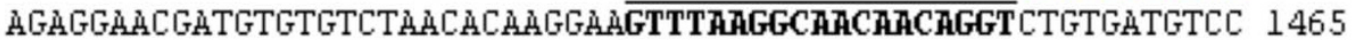
AGAGGAACGATGTGTGTCTAACACAAGGAAGTTTAHGGCACACACAGGTCTGTGATGTCC 1903

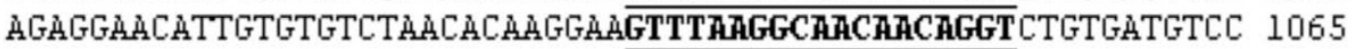

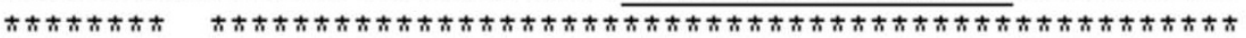
P. ovale
P. $v i v a x$
P. malariae
P. falciparum

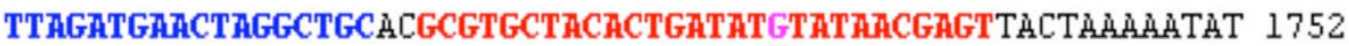

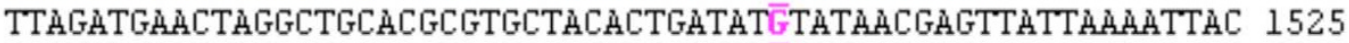
TTAGATGAACTAGGCTGCACGCGTGCTACACTGATATGTATẢCGAGTATTTAдẢĀTAT 1963

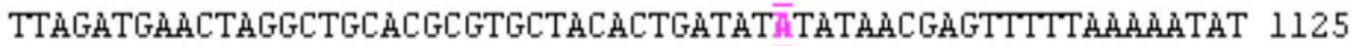

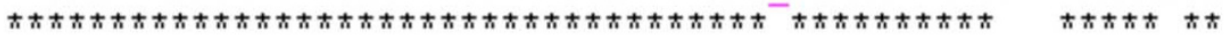
P. ovale
P. vivax
P. malariae
P. falciparum

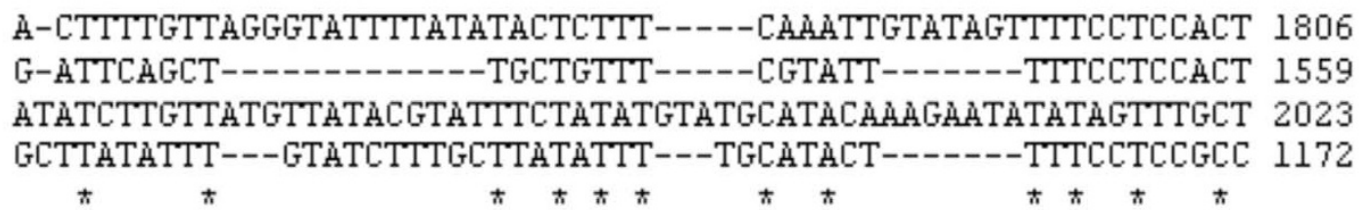

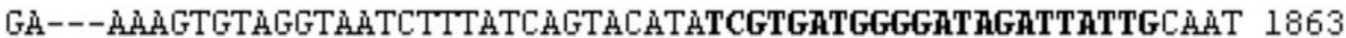

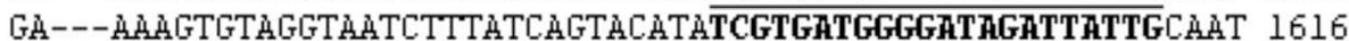

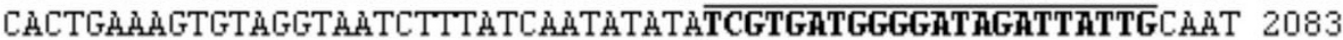

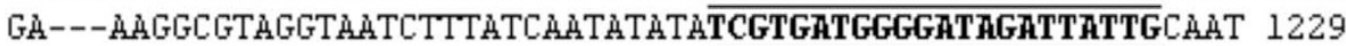

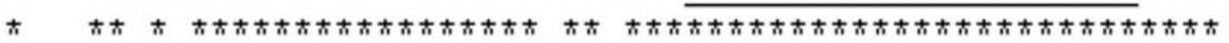

\section{Figure I}

Primer and fluorescence probe positions selected for FRET PCR of Plasmodium I8S rRNA gene. Sequences of forward (underline left panel) and reverse (underline right panel) primers were aligned with the corresponding target sequences. FRET probes for detection of parasite (blue and red for anchor and acceptor FRET hybridization probes, respectively). Acceptor FRET hybridization probe was designed on the basis of one nucleotide mismatch difference (shown in pink colour) that distinguish I8S rRNA gene of $P$. falciparum (GenBank Accession number: AL010278) from that of the $P$. vivax (GenBank Accession number: U83877) or P. ovale (GenBank Accession number: L48986) or P. malariae (GenBank Accession number: $\underline{\text { M54897). }}$

\section{Interpretative criteria}

The presence of an amplification or quantification curve for the LC705 signal captured in the F3 channel of the LightCycler, in conjunction with a melt curve with a melting temperature $(\mathrm{Tm})$ of about $60.0^{\circ} \mathrm{C}$, was considered a positive result for the $P$. falciparum; the presence of a quantification curve with a corresponding melt curve with a Tm of about $65.0^{\circ} \mathrm{C}$ was considered a negative result for the $P$. falciparum species and positive for at least one of the other three species. The absence of a quantification curve was considered as negative for the fourth species.

\section{Analytical sensitivity}

The minimum detection limit of the Plasmodium FRET assay was evaluated by use of a 10-fold dilution series of DNA (5000 to 0.25 parasites in a $20 \mu \mathrm{l}$ PCR reaction volume) extract from blood samples recovered from four patients infected with $P$. falciparum (parasitaemia: 0.01\% in Giemsa-stained thin blood smear). Each experiment included one reaction mixture without DNA as a negative control, and each specimen was run in duplicate for realtime PCR assay in parallel to conventional PCR.

\section{Analytical specificity}

To estimate the analytical specificity of the Plasmodium FRET assay, DNA was obtained and managed from European individuals who have never travelled to malaria endemic area $(n=10)$ or patients diagnosed with other infectious microorganisms (Toxoplasma gondii, Leishmania infantum, Pneumocistis carinii, Loa loa and Trypanosoma brucei gambiense, $\mathrm{n}=2$ samples for each microorganism).

Clinical specimen's sensitivity and specificity

The clinical sensitivity and specificity of the Plasmodium FRET assay for detecting and identifying malaria parasite species were calculated on 119 whole-blood samples, using conventional Giemsa-stained blood smear as the reference gold standard. 


\section{Conventional PCR amplification}

Two conventional PCR procedures were conducted: one with Plasmodium genus-specific primers (the same primers used in real-time PCR assay) and another with $P$. falciparum-specific primers. The PCR reaction was realized in a final volume of $50 \mu \mathrm{l}$ containing the following reagent mixture: $1 \times$ of PCR buffer $10 \times(500 \mathrm{mM} \mathrm{KCl}, 100 \mathrm{mM}$ Tris-HCl [pH 8.3], $20 \mathrm{mM} \mathrm{MgCl}_{2}$ ), $5 \mathrm{mM}$ concentration of $\mathrm{MgCl}_{2}, 0.5 \mu \mathrm{M}$ each oligonucleotide primer, $200 \mu \mathrm{M}$ deoxynucleoside triphosphate (Eurobio), and 0.02 unit Taq DNA polymerase (Eurobio). For each PCR tube, $40 \mu \mathrm{l}$ PCR reagent mixture and $10 \mu \mathrm{l}$ DNA were used. The reactions were carried out under the following conditions: (i) initial denaturation at $94^{\circ} \mathrm{C}$ for $3 \mathrm{mn}$, (ii) 35 cycles of: denaturation at $94^{\circ} \mathrm{C}$ for $30 \mathrm{~s}$, annealing at $58.5^{\circ} \mathrm{C}$ for 30 $\mathrm{s}$, extension at $72^{\circ} \mathrm{C}$ for $8 \mathrm{~s}$, and (iii) final extension at $72^{\circ} \mathrm{C}$ for $5 \mathrm{~min}$. Each experiment included one positive control (consisting of $P$. falciparum genomic DNA from positive blood samples) and one negative control (consisting of sterile double-distilled water). Amplified PCR products were detected by running $14 \mu \mathrm{l}$ of the PCR mixture on a standard $1.5 \%$ agarose gel stained with a $1.0 \mu \mathrm{g} /$ ml ethidium bromide solution and visualized under UV light.

\section{Statistical analysis}

The 95\% confidence intervals of proportions were calculated using the exact binomial test. Concordance between the results of real-time PCR and either conventional PCR assay or microscopy was analysed using the Kappa test [35]. All statistical analyses were performed using the SAS software (version 8.2).

\section{Results \\ Detection of Plasmodium genus and species differentiation}

DNA extracted from blood samples recovered from seven febrile patients harbouring Plasmodium species (Giemsastained blood smear positive) was used as a template for this assay: patients presenting with single species infections diagnosed by microscopical examination (two patients with red blood cells harbouring $P$. falciparum or $P$. vivax, and one with $P$. ovale or $P$. malariae) and one patient with red blood cells harbouring both $P$. falciparum and $P$. ovale. Typical amplification plots (change in fluorescent signal versus cycle numbers) with a $\mathrm{Ct}$ varying from 24.8 to 31.8 were obtained. Conventional PCR with genus-specific primers (the same primers used for realtime PCR) and DNA sequence analysis confirmed the specific amplification of the $18 \mathrm{~S}$ rRNA gene of Plasmodium species fragment. The FRET real-time PCR assay data allowed differentiating P. falciparum from the other three Plasmodium species. Mixed parasitism (P. falciparum plus non- $P$. falciparum) were identified by the presence of the two peaks simultaneously (Figure 2). The melting curve means Tms (standard deviation) were $61.0(0.8)^{\circ} \mathrm{C}$ for $P$. falciparum (means of three patients, two harbouring $P$. falciparum only and the other with two Plasmodium species) and $67.0(0.7){ }^{\circ} \mathrm{C}$ for the three other species (means of five individuals infected, four harbouring non-P. falciparum only and the other one mixed infection).

\section{Analytical sensitivity and specificity}

The sensitivity, inter- and intra-assay variabilities for four independent experiments are shown in Figure 3A. Positive signals (Ct values) were found for all dilutions except for 0.25 parasite per reaction. A detection limit of $0.5 \mathrm{P}$. falciparum per PCR volume was achievable. The Ct mean values (standard deviations), ranging from 27.9 (2.0) for 5000 parasites per PCR volume to $42.6(0.9)$ for 0.5 parasite per PCR volume. Amplification efficiency of real-time PCR reaction varied between 87 to $98 \%$ according to experiment (Figure 3B). A significant coefficient of correlation was found for the mean $\mathrm{Ct}$ values and $P$. falciparum concentration $(\mathrm{r}=-0.98)$ (Figure $3 \mathrm{~B})$. These DNA samples diluted were also amplified by conventional PCR with genus-specific primers and followed by electrophoresis and ethidium bromide staining (Figure 3C). The limit of detection was five parasites per PCR volume (Figure 3C). The conventional PCR assay was ten times less sensitive than the FRET real-time PCR assay. No PCR amplification by either real-time PCR, or conventional PCR with genusspecific primers was observed with any DNA samples obtained from European individuals who have never travel to malaria endemic area or patients infected with $T$. gondii, L. infantum, P. carinii, L. loa filaria or T. brucei gambiense.

\section{Clinical specimen sensitivity and specificity}

One hundred and nineteen febrile patients with a suspected clinical diagnosis of imported malaria were included in this study. Asexual parasitaemia means [95\% confidence interval or $\mathrm{CI}_{95 \%}$ ] at the inclusion was $0.7 \%$ [0.3-1.2] (Giemsa-stained blood smears microscopic examination). Two patients were gametocytaemic at day 0 , among which one harboured only gametocytes without asexual stages. Thirty-eight, 34 and three patients returning from Central (Gabon, Republic of Central Africa, Congo and Cameroon), Western (Benin, Burkina Faso, Ivory Cost, Guinea, Senegal and Togo) and Eastern (Kenya and Mozambique) African countries, respectively. Other patients travelled in Madagascar $(n=4)$, French Guyana $(\mathrm{n}=2)$, Comores $(\mathrm{n}=1)$ and Thailand $(\mathrm{n}=1)$. The geographical origin of parasites was not recorded for 36 patients.

Melting curve temperatures (Tms) of P. falciparum were defined as Tms of DNA samples that were positive by $18 \mathrm{~S}$ real-time PCR with only one melting curve and positive by conventional PCR using both genus- and P. falciparum-spe- 


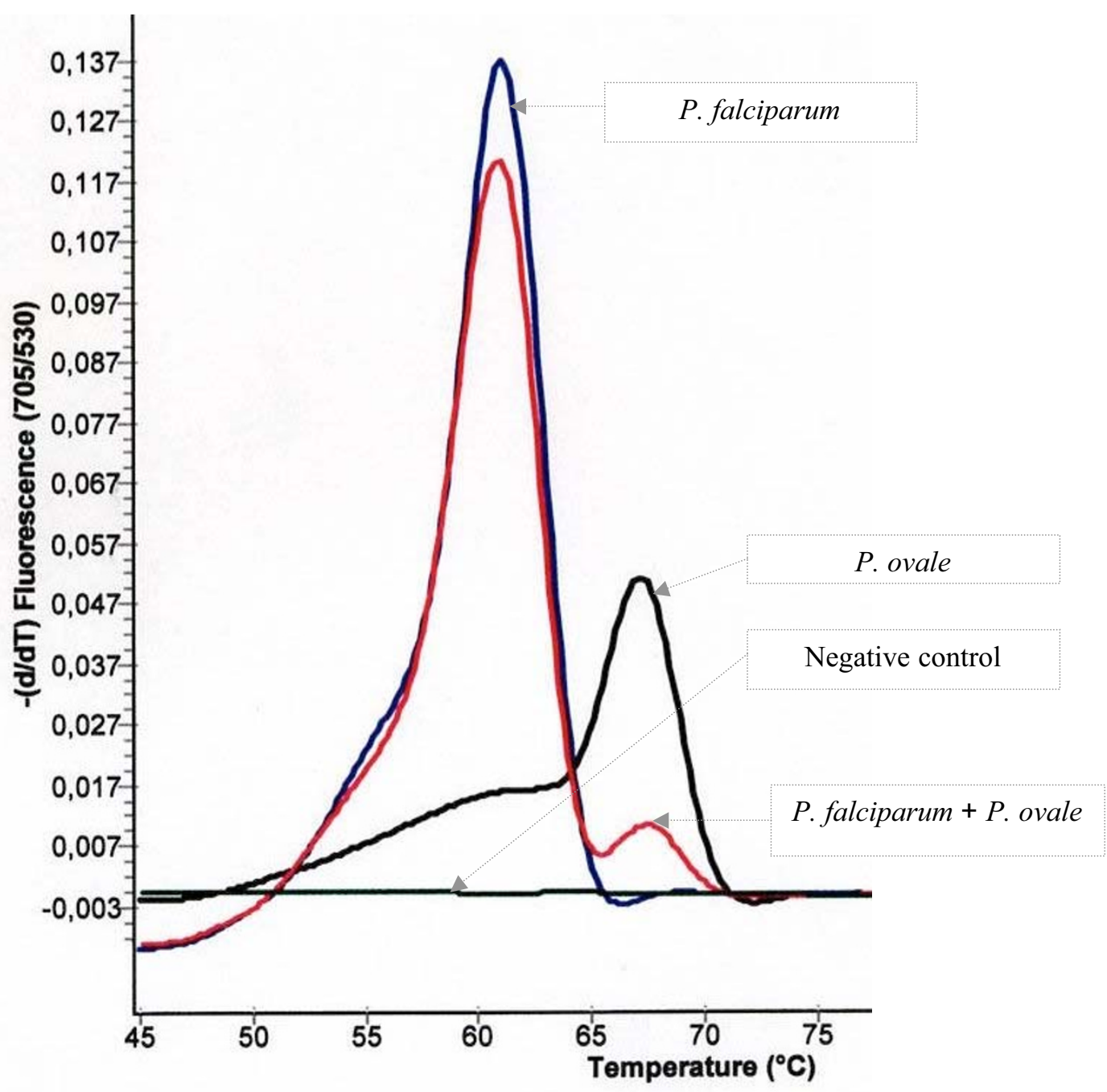

Figure 2

Melting curves of amplicons post real-time PCR of DNA extracted from three different blood samples with known $P$. falciparum, non-P. falciparum (P. ovale) and mixed Plasmodium sp. (P. falciparum $+P$. ovale). The Tms of the $P$. falciparum were distinctively lower than that of $P$. ovale. Negative control included reaction mixture with water.

cific primers. The Tms of non-P. falciparum species were defined as Tms of DNA samples that were $>$ than Tm values of $P$. falciparum, positive both by $18 \mathrm{~S}$ real-time PCR with only one melt in a curve and conventional PCR using genus-specific primers and, negative by conventional PCR using $P$. falciparum-specific primers. According to these definitions, we found that the melt curve means Tms (standard deviation) in clinical isolates were $60.5^{\circ} \mathrm{C}$ $\left(0.6^{\circ} \mathrm{C}\right)$ for $P$. falciparum DNA amplicons and $64.6^{\circ} \mathrm{C}$ $\left(1.8^{\circ} \mathrm{C}\right)$ for non-P. falciparum sp DNA amplicons. These results were closely related to melting temperature of 60.0 and $65.0^{\circ} \mathrm{C}$ for $P$. falciparum and non- $P$. falciparum sp respectively, that were estimated during primer and probe design using Oligo 4.0 software (LightCycler Probe Design Software, Roche). Tms of the P. falciparum or non$P$. falciparum species were similar between geographic origin of parasite (Figure 4).

\section{Real-time PCR and conventional PCR assays}

The results shown in Table 2 represent the comparison between $18 \mathrm{~S}$ real-time PCR and conventional PCR assays. Ninety one out of 119 DNA samples (76.5\%) were positive by both the $18 \mathrm{~S}$ screening real-time PCR and conventional PCR using genus-specific primers, whereas 26 samples were negative by both methods, giving a concordance rate of $98.3 \%\left(\mathrm{CI}_{95 \%}: 89.3\right.$ - 107.6) between real- 

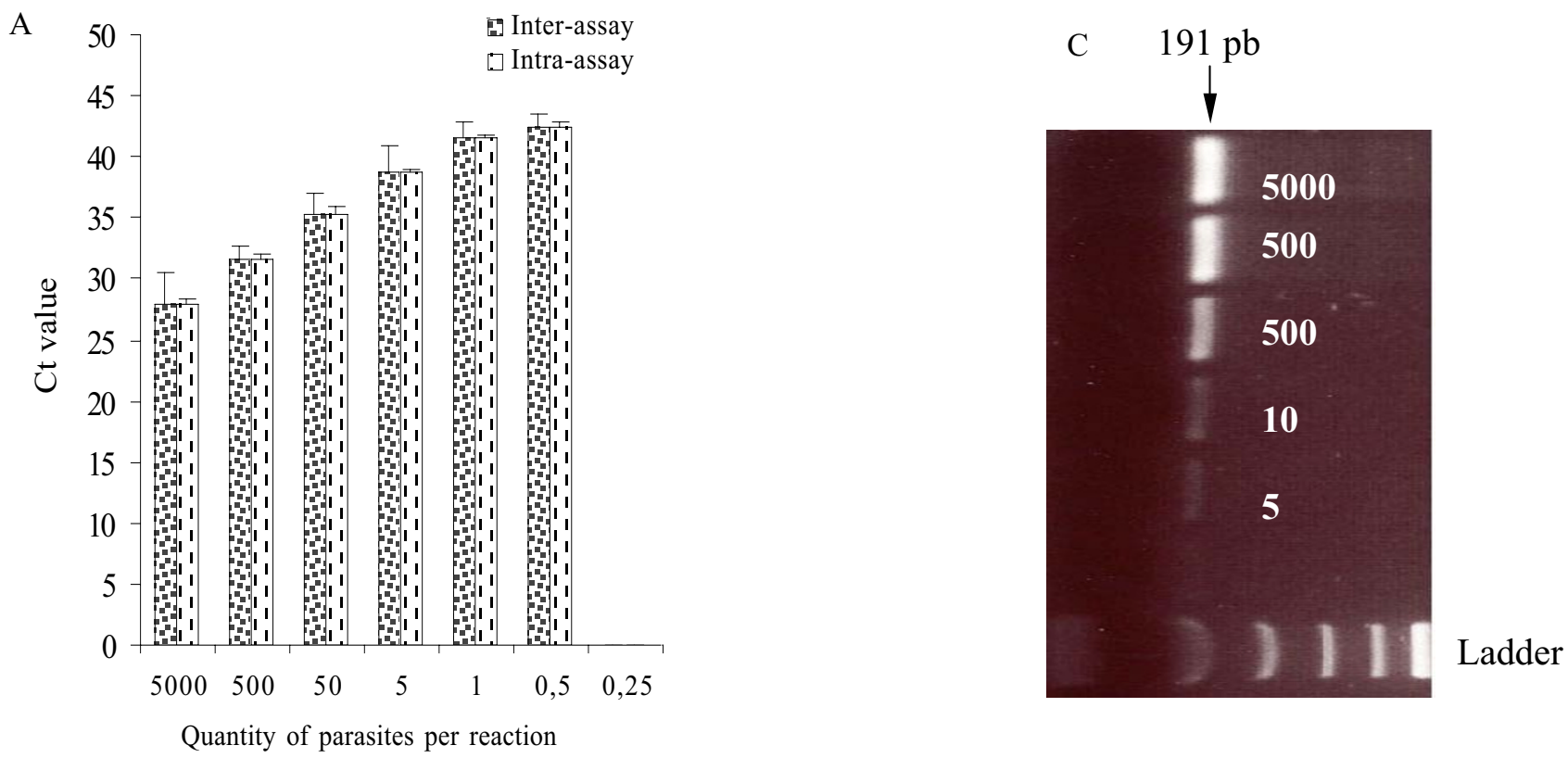

Quantity of parasites per reaction

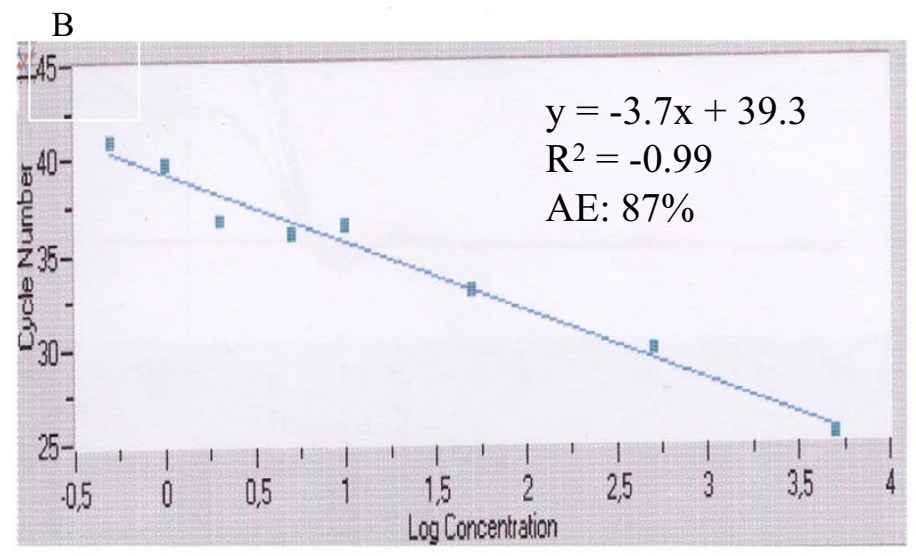

\section{Figure 3}

Sensitivity, inter- and intra-assay variabilities of $\boldsymbol{P}$. falciparum DNA quantification. (A) Results obtained from four independent tests in duplicate by real-time PCR assay using FRET. (B) Linearity of FRET assay PCR is shown using serially diluted $P$. falciparum DNA (5000 to 0.25 parasites per reaction, one representative experiment). Amplification efficiency (AE) is calculated based on the slope of the standard curves using the formula: $E=10^{1 /-s}-I$, where $E(I 00)$ is the \% efficiency and $s$ is the slope of the standard cure. (C) Amplification of serially diluted $P$. falciparum DNA (5000 to 5 parasites per PCR reaction) by conventional PCR assay followed by gel electrophoresis and ethidium bromide staining.

time PCR assay and conventional PCR using genus-specific primers (Kappa coefficient: 0.95, $\mathrm{CI}_{95 \%}$ : 0.9 - 1). Two $(1.7 \%)$ DNA samples positive by real-time PCR assay were negative by conventional PCR assay using genus-specific test (Table 2). Seventy one out of 119 DNA samples (59.7\%) were positive by both the $18 \mathrm{~S}$ real-time PCR and conventional PCR using P. falciparum-specific primers, whereas 26 samples were negative by both methods, giving a concordance rate of $96.6 \%\left(\mathrm{CI}_{95 \%}: 87.6-105.6\right)$ between real-time PCR assay and conventional PCR using genus-specific primers (Kappa coefficient: 0.91, $\mathrm{CI}_{95 \%}: 0.8$ - 1). Four (3.4\%) DNA samples identified as $P$. falciparum by real-time PCR assay were negative by conventional PCR assay using $P$. falciparum-specific primers (Table 2 ).

\section{Real-time PCR and microscopy}

Eighty six out of 119 DNA samples (72.3\%) were positive by both the real-time PCR and microscopy, whereas 26 


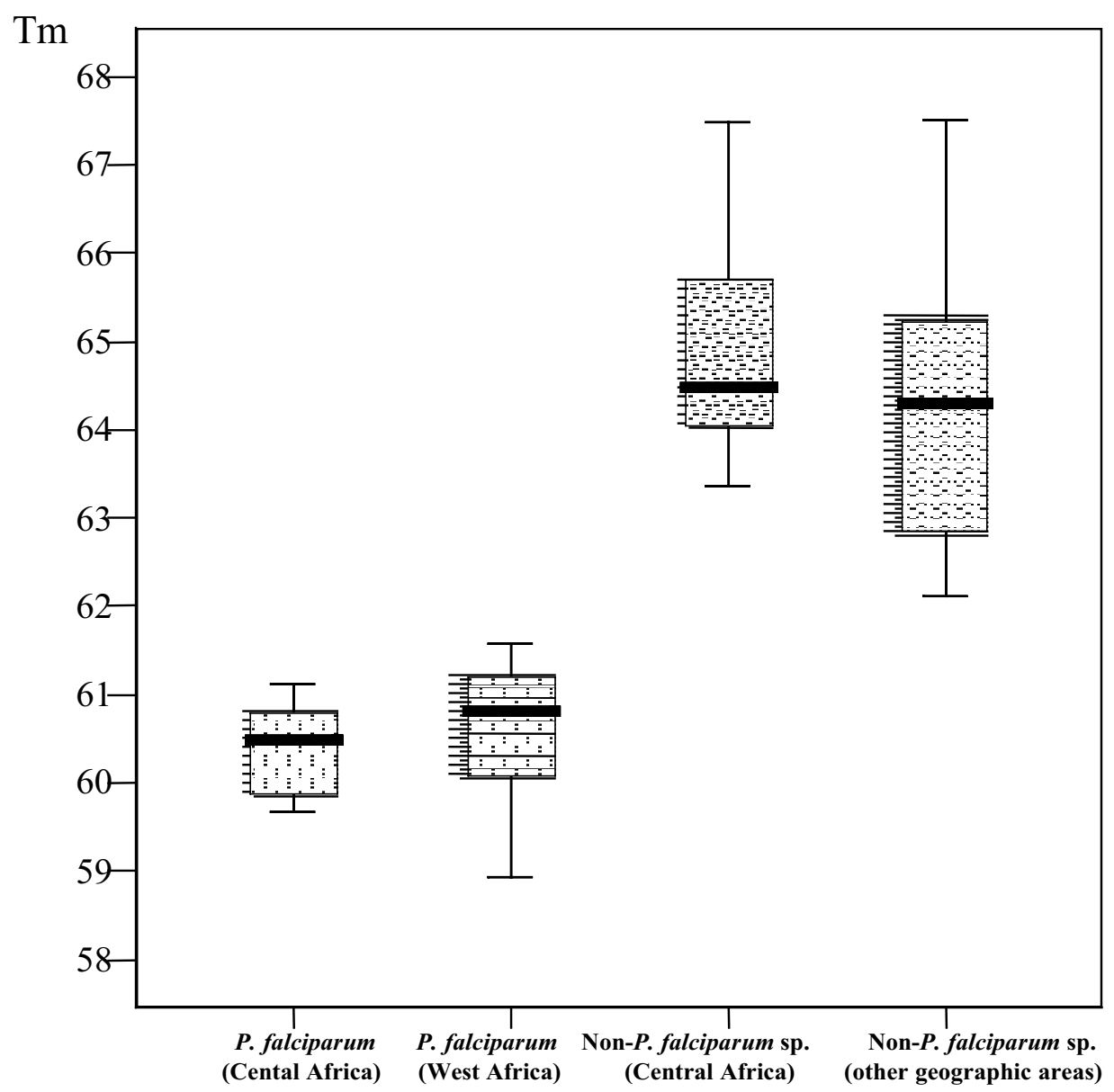

\section{Figure 4}

Amplicon melting temperature plots (Tms) of $\boldsymbol{P}$. falciparum and non- $\boldsymbol{P}$. falciparum sp. according to the geographic origin of infection. Tms of the $P$. falciparum or Non- $P$. falciparum species were similar between origin of parasite. $n$, effective.

samples were negative by both methods, giving a concordance rate of $94.1 \%\left(\mathrm{CI}_{95 \%}: 85.1\right.$ - 103.1) between microscopy and real-time PCR for detection of any Plasmodium species (Table 3). A full agreement for Plasmodium sp. detection and species differentiation between both assays was found (Kappa coefficient: 0.70, $\mathrm{CI}_{95 \%}$ : $0.6-0.8$ ). Seven patients identified with Giemsa-stained blood smear as negative were positive with real-time PCR (five as $P$. falciparum infection and two as non- $P$. falciparum species). Eight DNA samples with undetermined species by microscopy were identified as $P$. falciparum by the realtime PCR (Table 3). These results were confirmed by conventional PCR assays using both genus- and P. falciparumspecific primers. The real-time PCR was able to detect mixed infection ( $P$. falciparum + non-P. falciparum species). Two patient samples positive for $P$. ovale (Giemsastained films) were recorded as samples harbouring $P$. fal- ciparum and non-P. falciparum species with real-time PCR assay. One patient which microscopic result was mixed infection ( $P$. falciparum and $P$. vivax, $2.6 \%$ and $<0.01 \%$ of parasitaemia, respectively) was also identified as mixed infection ( $P$. falciparum + non-P. falciparum sp.) with realtime PCR assay (Table 3). However, three patients with Giemsa-stained films positive for mixed infection (P. falciparum and P. malariae) were mono-infection with realtime PCR assay ( 2 patients with $P$. falciparum and one with non-P. falciparum sp.) (Table 3$)$.

\section{Discussion}

A real-time PCR method using the FRET system for detection of malaria parasites, with simultaneous differentiation of the most threatening parasite $P$. falciparum from the three other Plasmodium species (P. vivax, P. ovale and $P$. malariae) was described. In order to increase the sensitivity 
Table 2: Detection of Plasmodium DNA by real-time and conventional PCR assays in patients at day of inclusion

\begin{tabular}{|c|c|c|c|c|c|}
\hline & & \multicolumn{4}{|c|}{ Conventional PCR, no. of patients } \\
\hline & & \multicolumn{2}{|c|}{ Genus-specific primers } & \multicolumn{2}{|c|}{ P. falciparum-specific primers } \\
\hline & & POS(a) & NEG(b) & POS(a) & NEG(b) \\
\hline \multirow[t]{4}{*}{ Real-Time PCR } & P. falciparum & 71 & I & 68 & 4 \\
\hline & Non-P. falciparum sp. & 17 & 1 & 0 & 18 \\
\hline & Mixed Plasmodium sp.(c) & 3 & 0 & 3 & 0 \\
\hline & NEG(b) & 0 & 26 & 0 & 26 \\
\hline
\end{tabular}

(a)POS, posiive; (b)NEG, negative; (c)Mixed Plasmodium sp, P. falciparum + non-P. falciparum sp.

of the assay, a species-specific region of the Plasmodium $18 \mathrm{~S}$ (small subunit) rRNA gene was targeted, as this gene contains multiple copies dispersed throughout the Plasmodium genome [36]. The real-time PCR results were compared with those of conventional PCR and microscopy.

The proposed protocol was performed in 90 minutes, including 30 minutes for DNA extraction, 15 minutes for mix preparation, and 45 minutes for amplification and results interpretation. In clinical isolates obtained from returned travellers, an equivalent concordance rate between real-time PCR assay and conventional PCR $(\geq$ $97 \%$ ) or microscopic (94\%) was found. The specificity to detect Plasmodium sp. was $100 \%$ and the real-time PCR assay was able to detect parasitaemia less than $0.01 \%$ (microscopy examination). The proposed PCR method demonstrates a higher sensitivity to identify cryptic malaria infections. Seven febrile patients with negative Giemsa-stained films were positive with real-time PCR method. The analytical real-time PCR assay threshold was 0.5 compared to five parasites per PCR reaction with conventional PCR assay using genus-specific primers (the same primer used for real-time PCR assay). This sensitivity is more important than that was previously obtained by Swan and colleagues using similar approach [31], and correspond favourably to other published methods, specifi- cally real-time PCR assays using TaqMan probes $[23,25,27,37]$. This high sensitivity is very important in term of biological diagnostic of imported malaria, as many returning travellers and migrants, sometimes under prophylactic medication or auto-medication, display febrile symptoms with very low-grade parasitaemia. In some case, parasite morphology is damaged due to exposition to prophylactic medication or auto-medication, making malaria biological diagnosis using microscopy more difficult.

The set of DNA primer and probe proposed in this study demonstrated a high specificity to differentiate $P$. falciparum from the three other Plasmodium species (P. vivax, $P$. malariae and $P$. ovale), based on the melting curve. Monoinfections were systematically identified, and realtime PCR has been even more effective than microscopy examination, identifying undetermined parasites, identified as Plasmodium sp. by microscopist due to the lack of specific form of parasites or morphological damages often resulting from previous or current antimalarial treatment. The real-time PCR assay was able to identify mixed infection (P. falciparum and non-P. falciparum sp.) and individual harbouring only gametocytes or gametocytes and asexual stages from different malaria Plasmodium species. Two patients who Giemsa-stained films were positive for

Table 3: Detection of Plasmodium species by microscopy and real-time PCR in patients at day of inclusion

\begin{tabular}{|c|c|c|c|c|c|}
\hline & & \multicolumn{4}{|c|}{ Real-time PCR, no. of patients } \\
\hline & & \multicolumn{3}{|c|}{ POS(a) } & \multirow[t]{2}{*}{ NEG(b) } \\
\hline & & P. falciparum & non-P. falciparum sp & Mixed Plasmodium sp.(c) & \\
\hline \multirow[t]{7}{*}{ Microscopy } & P. falciparum & 54 & 0 & 0 & 0 \\
\hline & P. ovale & 2 & 7 & 2 & 0 \\
\hline & P. malariae & 0 & 2 & 0 & 0 \\
\hline & P. vivax & I & 6 & 0 & 0 \\
\hline & Plasmodium sp & 8 & 0 & 0 & 0 \\
\hline & Mixed infection & 2 & 1 & I & 0 \\
\hline & NEG(b) & 5 & 2 & 0 & 26 \\
\hline
\end{tabular}

(a)POS, positive; (b)NEG, negative; (c)Mixed Plasmodium sp, P. falciparum + non-P. falciparum sp. 
P. ovale infection display mixed infection with real-time PCR assay. The validity of these results was supported by the clear visualization of two separate fluorescence peaks at different melting temperatures $\left(59.7^{\circ} \mathrm{C}\right.$ and $66.9^{\circ} \mathrm{C}$, $59.5^{\circ} \mathrm{C}$ and $64.9^{\circ} \mathrm{C}$, for the two assays), which correspond to the melting curve Tms of $P$. falciparum (60.5 \pm $\left.0.6^{\circ} \mathrm{C}\right)$ and non-P. falciparum sp. $\left(64.6 \pm 1.8^{\circ} \mathrm{C}\right)$. The detection of $P$. falciparum plus $P$. malariae mixed infection was not resolved. Three patients with mixed infection by microscopy $(P$. falciparum and $P$. malariae with parasitaemia density of $P$. malariae $<0.01 \%$ ) were identified as $P$. falciparum mono-infection $(\mathrm{n}=2)$ or non- $P$. falciparum $\mathrm{sp}$. mono-infection $(\mathrm{n}=1)$ with real-time PCR assay. This discrepancy was also observed in experimental mixed infection with $P$. falciparum and $P$. malariae. The low number of included patients harbouring mixed infection make that more experiments need to be conducted in order to precise detection limit of parasites in the case of mixed infections. Precise identification of the presence of $P$. falciparum associated or not with other Plasmodium species is a critical issue for patient care and treatment outcome, since i) $P$. falciparum infections are potentially fatal and ii) drug resistance occur at a high level compared to other species.

Geographically diverse malaria isolates obtained from returning febrile travellers and migrants were analysed to ensure that the assay would reliably differentiate $P$. falciparum from the three other species despite the parasite origin. The result indicates that the single base pair mismatched which allowed differentiation of $P$. falciparum to the three other species is well conserved between geographic regions of parasite which was evaluated. Single base differences theoretically may also exist between strains within a species from different geographic regions, but our results indicate that no variance was found among individual isolates. Additional specimens from other regions around the world would be required to confirm these observations.

Recently, Plasmodium knowlesi, a species that has morphological similarities with $P$. malariae, has been identified as a human pathogen in patients from Malaysia [38]. Sequence analysis indicates that this species may also be amplified by using the set of primer and probe proposed in this study, and the expected Tm will be similar to that of non- $P$. falciparum species. Further confirmations are needed by testing $P$. knowlesi specimens with this real-time PCR method.

\section{Conclusion}

A rapid, FRET real-time PCR assay using one set of primer and probe for the diagnosis of Plasmodium sp. in febrile returning travellers and migrants was described. An important advantage of this approach is the higher sensi- tivity and specificity for the detection of Plasmodium sp. and to differentiate $P$. falciparum from the three other malaria parasite species ( $P$. vivax, $P$. malariae and $P$. ovale), based on the melting. Concurrently to microscopic examination, such results can be used to ensure rapid treatment administration and proper follow-up of the malaria attacks by the practitioner. Except for $P$. falciparum and $P$. malariae mixed infection, the ability to provide accurate species identification in the same sample used for detection of the parasite is also a greatest attribute of this method. The proposed protocol is performed through automated extraction, amplification and interpretation allowing access to any laboratory technician without specific knowledge in the field of malaria. Although the relatively high cost of real-time PCR technology may preclude its use in resource-poor clinics, its performance characteristics, combined with its rapid results, suggest that it may be a useful diagnostic adjunct in industrialized countries.

\section{Authors' contributions}

IS participated in conceptualising the real-time PCR assay, contributed to the design of the study, conducted the PCR methods and wrote the first draft of the manuscript. LM conducted the PCR methods and participated to drafting of the manuscript. SB, PM and HF participated in conceptualising the real-time PCR method, contributed to the design of the study and critically reviewed the manuscript. $\mathrm{FF}, \mathrm{PF}$ and PV processed the isolates and read slides and critically reviewed the manuscript. CR and TP contributed to the enrolment of patients and critically reviewed the manuscript. DM contributed to the design of the study, supervised the enrolment of patients and critically reviewed the manuscript. All authors read and approved the final manuscript.

\section{Acknowledgements}

The authors are grateful to Drs Genevieve Milon, Denise Mattei and Thierry Fandeur for their helpful comments and critical review of the manuscript. IS was supported by a fellowship ("Bourse d'Excellence") from the French Ministry of Foreign affairs.

\section{References}

I. Sachs J, Malaney P: The economic and social burden of malaria. Nature 2002, 41 5:680-685.

2. Kain KC, Keystone JS: Malaria in travelers. Epidemiology, disease, and prevention. Infect Dis Clin North Am 1998, 12:267-284.

3. Trampuz A, Jereb M, Muzlovic I, Prabhu RM: Clinical review: Severe malaria. Crit Care 2003, 7:315-323.

4. Kain KC, Harrington MA, Tennyson S, Keystone JS: Imported malaria: prospective analysis of problems in diagnosis and management. Clin Infect Dis 1998, 27: 142-149.

5. Kain KC, MacPherson DW, Kelton T, Keystone JS, Mendelson J, MacLean JD: Malaria deaths in visitors to Canada and in Canadian travellers: a case series. Canadian Medical Association Journal 200I, 164:654-659.

6. Mühlberger N, Jelinek T, Behrens RH, Gjørup I, Coulaud JP, Clerinx J, Puente S, Burchard G, Gascon J, Grobusch MP, Weitzel T, Zoller T, Kollaritsch H, Beran J, Iversen J, Hatz C, Schmid ML, Björkman A, Fleischer K, Bisoffi Z, Guggemos W, Knobloch J, Matteelli A, Schulze $\mathrm{MH}$, Laferl H, Kapaun A, McWhinney P, Lopez-Velez R, Fätkenheuer G, Kern P, Zieger BW, Kotlowski A, Fry G, Cuadros J, Myrvang B: 
Age as a risk factor for severe manifestations and fatal outcome of falciparum malaria in European patients: observations from TropNetEurop and SIMPID Surveillance Data. Clin Infect Dis 2003, 36:990-995.

7. Newman RD, Parise ME, Barber AM, Steketee RW: Malaria-related deaths among U.S. travelers, I 963-200 I. Ann Intern Med 2004, | 4 | :547-555.

8. Amexo M, Tolhurst R, Barnish G, Bates I: Malaria misdiagnosis: effects on the poor and vulnerable. Lancet 2004, 364: 1896- I898.

9. Morgan UM, Thompson RC: Molecular detection of parasitic protozoa. Parasitology 1998, I I 7:S73-85.

10. Moody $\mathrm{AH}$, Chiodini PL: Methods for the detection of blood parasites. Clin Lab Haematol 2000, 22: 189-20I.

II. Snounou G, Viriyakosol S, Jarra W, Thaithong S, Brown KN: Identification of the four human malaria parasite species in field samples by the polymerase chain reaction and detection of a high prevalence of mixed infections. Mol Biochem Parasitol 1993, 58:283-292.

12. Milne LM, Kyi MS, Chiodini PL, Warhurst DC: Accuracy of routine laboratory diagnosis of malaria in the United Kingdom. J Clin Pathol 1994, 47:740-742.

13. Singh B, Bobogare A, Cox-Singh J, Snounou G, Abdullah MS, Rahman HA: A genus- and species-specific nested polymerase chain reaction malaria detection assay for epidemiologic studies. Am J Trop Med Hyg 1999, 60:687-692.

14. Ohrt C, Purnomo, Sutamihardja MA, Tang D, Kain KC: Impact of microscopy error on estimates of protective efficacy in malaria-prevention trials. J Infect Dis 2002, 186:540-546.

15. McKenzie FE, Sirichaisinthop J, Miller RS, Gasser RA Jr, Wongsrichanalai C: Dependence of malaria detection and species diagnosis by microscopy on parasite density. Am J Trop Med Hyg 2003, 69:372-376.

16. Moody A: Rapid diagnostic tests for malaria parasites. Clin Microbiol Rev 2002, 15:66-78.

17. Mills CD, Burgess DC, Taylor HJ, Kain KC: Evaluation of a rapid and inexpensive dipstick assay for the diagnosis of Plasmodium falciparum malaria. Bull World Health Organ 1999, 77:553-559.

18. Cropley IM, Lockwood DN, Mack D, Pasvol G, Davidson RN: Rapid diagnosis of falciparum malaria by using the ParaSight $F$ test in travellers returning to the United Kingdom: prospective study. BMJ 2000, 321:484-485.

19. Gunderson JH, Sogin ML, Wollett G, Hollingdale M, de la Cruz VF Waters AP, McCutchan TF: Structurally distinct, stage-specific ribosomes occur in Plasmodium. Science 1987, 238:933-937.

20. Kawamoto F, Miyake H, Kaneko O, Kimura M, Nguyen TD, Nguyen TD, Liu Q, Zhou M, Le DD, Kawai S, Isomura S, Wataya $Y$ Sequence variation in the I8S rRNA gene, a target for PCRbased malaria diagnosis, in Plasmodium ovale from southern Vietnam. J Clin Microbiol 1996, 34:2287-2289.

21. Seesod N, Nopparat P, Hedrum A, Holder A, Thaithong S, Uhlen M, Lundeberg J: An integrated system using immunomagnetic separation, polymerase chain reaction, and colorimetric detection for diagnosis of Plasmodium falciparum. Am J Trop Med Hyg 1997, 56:322-328.

22. Bruna-Romero O, Hafalla JC, Gonzalez-Aseguinolaza G, Sano G, Tsuji $M$, Zavala $F$ : Detection of malaria liver-stages in mice infected through the bite of a single Anopheles mosquito using a highly sensitive real-time PCR. Int J Parasitol 200 I, 3 I: I 499- I502.

23. Hermsen CC, Telgt DS, Linders EH, van de Locht LA, Eling WM, Mensink E], Sauerwein RW: Detection of Plasmodium falciparum malaria parasites in vivo by real-time quantitative PCR. Mol Biochem Parasitol 200I, I I 8:247-25I.

24. Witney AA, Doolan DL, Anthony RM, Weiss WR, Hoffman SL Carucci DJ: Determining liver stage parasite burden by real time quantitative PCR as a method for evaluating pre-erythrocytic malaria vaccine efficacy. Mol Biochem Parasitol 200I, I I 8:233-245.

25. Lee MA, Tan CH, Aw LT, Tang CS, Singh M, Lee SH, Chia HP, Yap EP: Real-time fluorescence-based PCR for detection of malaria parasites. J Clin Microbiol 2002, 40:4343-4345.

26. de Monbrison F, Angei C, Staal A, Kaiser K, Picot S: Simultaneous identification of the four human Plasmodium species and quantification of Plasmodium DNA load in human blood by real-time polymerase chain reaction. Trans $R$ Soc Trop Med Hyg 2003, 97:387-390.
27. Perandin F, Manca N, Calderaro A, Piccolo G, Galati L, Ricci L, Medici MC, Arcangeletti MC, Snounou G, Dettori G, Chezzi C: Development of a real-time PCR assay for detection of Plasmodium falciparum, Plasmodium vivax, and Plasmodium ovale for routine clinical diagnosis. J Clin Microbiol 2004, 42: I2I4-I219.

28. Katakai Y, Chiabchalard R, Komaki-Yasuda K, Kawazu S, Singhasivanon P, Krudsood S, Looareesuwan S, Kano S: Application of real-time polymerase chain reaction (PCR) analysis for detection and discrimination of malaria parasite species in Thai patients. Southeast Asian J Trop Med Public Health 2004, 35:10-14.

29. Elsayed S, Plewes K, Church D, Chow B, Zhang K: Use of molecular beacon probes for real-time PCR detection of Plasmodium falciparum and other Plasmodium species in peripheral blood specimens. I Clin Microbiol 2006, 44:622-624.

30. Farcas GA, Soeller R, Zhong K, Zahirieh A, Kain KC: Real-time polymerase chain reaction assay for the rapid detection and characterization of chloroquine-resistant Plasmodium falciparum malaria in returned travelers. Clin Infect Dis 2006, 42:622-627.

3I. Swan H, Sloan L, Muyombwe A, Chavalitshewinkoon-Petmitr P, Krudsood S, Leowattana W, Wilairatana P, Looareesuwan S, Rosenblatt J: Evaluation of a real-time polymerase chain reaction assay for the diagnosis of malaria in patients from Thailand. Am J Trop Med Hyg 2005, 73:850-854.

32. Mangold KA, Manson RU, Koay ES, Stephens L, Regner M, Thomson RB Jr, Peterson LR, Kaul KL: Real-time PCR for detection and identification of Plasmodium spp. J Clin Microbiol 2005, 43:2435-2440.

33. Ririe KM, Rasmussen RP, Wittwer CT: Product differentiation by analysis of DNA melting curves during the polymerase chain reaction. Anal Biochem 1997, 245:154-160.

34. Waters AP, McCutchan TF: Rapid, sensitive diagnosis of malaria based on ribosomal RNA. Lancet 1989, I: |343-1346.

35. Fermanian J: [Measurement of agreement between $\mathbf{2}$ judges. Qualitative cases]. Rev Epidemiol Sante Publique 1984, 32: I 40- | 47.

36. Gardner MJ, Hall N, Fung E, White O, Berriman M, Hyman RW, Carlton JM, Pain A, Nelson KE, Bowman S, Paulsen IT, James K, Eisen JA, Rutherford K, Salzberg SL, Craig A, Kyes S, Chan MS, Nene V, Shallom S], Suh B, Peterson J, Angiuoli S, Pertea M, Allen J, Selengut J, Haft $D$, Mather MW, Vaidya AB, Martin DM, Fairlamb AH, Fraunholz MJ, Roos DS, Ralph SA, McFadden GI, Cummings LM, Subramanian GM, Mungall C, Venter JC, Carucci DJ, Hoffman SL, Newbold C, Davis RW, Fraser CM, Barrell B: Genome sequence of the human malaria parasite Plasmodium falciparum. Nature 2002, 4I9:498-5II.

37. Rougemont M, Van Saanen M, Sahli R, Hinrikson HP, Bille J, Jaton K: Detection of four Plasmodium species in blood from humans by 185 rRNA gene subunit-based and species-specific realtime PCR assays. J Clin Microbiol 2004, 42:5636-5643.

38. Singh B, Kim Sung L, Matusop A, Radhakrishnan A, Shamsul SS, CoxSingh J, Thomas A, Conway DJ: A large focus of naturally acquired Plasmodium knowlesi infections in human beings. Lancet 2004, 363:1017-1024.

Publish with Bio Med Central and every scientist can read your work free of charge

"BioMed Central will be the most significant development for disseminating the results of biomedical research in our lifetime. "

Sir Paul Nurse, Cancer Research UK

Your research papers will be:

- available free of charge to the entire biomedical community

- peer reviewed and published immediately upon acceptance

- cited in PubMed and archived on PubMed Central

- yours - you keep the copyright
BioMedcentral 